\title{
Prevalence of vaccine-derived polioviruses in sewage and river water in South Africa
}

\author{
D.N. Pavlov, W.B. Van Zyl, J. Van Heerden, W.O.K. Grabow and M.M. Ehlers \\ Department of Medical Virology, University of Pretoria/NHLS, P.O. Box 2034, \\ Pretoria 0001, South Africa
}

\begin{abstract}
Polioviruses (PVs) are not associated with waterborne transmission to the same extent as many other enteric viruses. However, they are typically transmitted by the faecal-oral route, which implies that the risk of infection by exposure to the viruses in water cannot be underestimated. The risk appears particularly high for rural communities, which use sewage-polluted river water for domestic purposes. Thus, the presence in the environment of highly evolved, neurovirulent vaccine-derived poliovirus (VDPV) strains in the absence of polio cases would have important implications for strategies to terminate immunisation with oral poliovirus vaccine (OPV) following global polio eradication. The aim of the current study was to determine the prevalence of VDPVs in selected sewage and river water samples collected from 2001 to 2003, and to construct phylogenetic trees of the partially sequenced 5'untranslated region (5'UTR) and the VP1 region of the genomes to deduce the genetic relatedness between the PV strains. Using the monolayer plaque assay, 703 plaques from sewage and 157 plaques from river water samples were analysed. Application of a RT-multiplex PCR revealed that 176 of these plaques were non-polio enteroviruses, and 49 were PV isolates. The Sabin-specific RTtriplex PCR revealed the presence of 29 Sabin PV type 1, 8 Sabin PV type 2 and 12 Sabin PV type 3 isolates. The 5'UTR and the VP1 region of 13 PV type 1, 7 PV type 3 and 6 PV type 2 isolates were partially sequenced. The majority of the OPV isolates (24 out of 26) displayed close sequence relationships ( $>99 \%$ VP1 sequence identity) to the parental Sabin PV vaccine strains and were classified as "OPV-like viruses". Two isolates (D1 $08 / 28$ and OF1 05/21) were found to be highly divergent and were classified as "suspected" VDPVs. Isolate OF1 05/21 (a "suspected" VDPV type 1) showed more than $0.9 \%$ divergence in VP1, whereas isolate D1 08/28 (a "suspected" VDPV type 2) showed $1.4 \%$ divergence in VP1 from the parental Sabin PV vaccine strains. As with most of the other OPV-like isolates, these "suspected" VDPVs were carrying mutations, which have previously been associated with reversion of the attenuated Sabin PV strains to increased neurovirulence. It was estimated that the total period of replication for the two "suspected" VDPVs was between 12 and 16 months. In conclusion, this study provided new and relevant information on the prevalence of "suspected" VDPVs in sewage and
\end{abstract}


river water, and opened the way to assess the possible broader significance of the findings reported here.

Abbreviations: AFP, Acute flaccid paralysis; ATCC, American type culture collection; BGM, Buffalo green monkey kidney; cVDPV, Circulating vaccine-derived poliovirus; CPE, Cytopathogenic effect; DNA, Deoxyribonucleic acid; EVs, Enteroviruses; ECACC, European collection of cell culture; HEp-2, Human epidermoid carcinoma; NPEVs, Nonpolio enteroviruses; OPV, Oral poliovirus vaccine; PBS, Phosphate-buffered saline; PEG, Polyethylene glycol; PV, Poliovirus; PLC/PRF/5, Primary liver carcinoma; RT-PCR, Reverse transcription polymerase chain reaction; RNA, Ribonucleic acid; UTR, Untranslated region; VAPP, Vaccine-associated paralytic poliomyelitis; VDPV, Vaccinederived poliovirus; VP, Virus protein; WHO, World Health Organisation.

\section{Article Outline}

1. Introduction

2. Materials and methods

2.1. Virus stock and cell cultures

2.2. Isolation of polioviruses from sewage and river water

2.3. Ribonucleic acid extraction and primary molecular characterisation of virus isolates

2.4. Sabin specific RT-triplex PCR

2.5. RT-PCR amplification of the 5'untranslated region of polioviruses

2.6. RT-PCR amplification of the vp1 capsid protein of polioviruses

2.7. Nucleotide sequencing and phylogenetic analysis

2.8. Nucleotide sequence accession numbers

3. Results and discussion

3.1. Phylogenetic analysis of the 5'UTR of the poliovirus genome

3.2. Phylogenetic analysis of the VP1 region of the poliovirus genome

4. Conclusions

Acknowledgements

References

\section{Introduction}

The polio eradication program is close to the final stage of replacing wild-type poliovirus (PV) in the population with vaccine-type by mass live attenuated oral poliovirus vaccine (OPV) immunisation (Yoshida et al., 2002). Mutations of the PV vaccine strains during genomic replication in the gastrointestinal tract may result in loss of attenuation and an increase in neurovirulence (Wood and Thorley, 2003). If the mutations lead to 
poliomyelitis in a vaccine recipient or close contact it is defined as vaccine-associated paralytic poliomyelitis (VAPP) (Wood and Thorley, 2003).

All clinical and environmental PV isolates that are related to OPV strains are vaccinederived polioviruses (VDPVs) (World Health Organization [WHO], 2004). The extensive sequence divergence from the respective OPV strain is a distinguishing feature of VDPVs (Kew et al., 1998; Bellmunt et al., 1999; Martin et al., 2000; Kew et al., 2004).

Derivatives of the Sabin live attenuated vaccine strains present in OPV have been classified into two broad categories for programmatic reasons (WHO, 2004). A vaccinerelated isolate is considered a VDPV if it has diverged by $\geqslant 1 \%$ of VP1 nucleotides from the reference OPV strain (WHO, 2002; Kew et al., 2004; WHO, 2004). The demarcation of $1 \%$ VP1 divergence implies that replication of vaccine virus had occurred for approximately 1 year (Kew et al., 2004; WHO, 2004). The vast majority of vaccine related isolates are "OPV-like viruses" and have close sequence relationships $(<1 \%$ VP1 sequence divergence) to the original OPV strains (WHO, 2004). Isolates having $<1 \%$ divergence would not necessarily lack the capacity for person-to-person transmission in poorly immunised populations, as it is likely that the critical attenuating mutations of the Sabin PV strains generally revert before nucleotide substitutions accumulate to the level of $1 \%$ (Kew et al., 2004; WHO, 2004). By this definition, nearly all minimally diverged "OPV-like" isolates would be excluded and VDPVs that had replicated for at least one year would be included (Kew et al., 2004; WHO, 2004). A VDPV may cause an outbreak of poliomyelitis and if there is evidence of person-to-person transmission, based on epidemiological and phylogenetic studies, it is defined as a circulating VDPV (cVDPV) (Wood and Thorley, 2003; Kew et al., 2004).

A study conducted by Divizia and colleagues (1999), confirmed the environmental circulation in Albania of recombinant PV strains (Sabin-like PV type 2/wild PV type 1), sustained by a massive immunisation effort and by the presence in the environment of a PV type 1, isolated from a river 2 months before the first case of symptomatic acute flaccid paralysis (AFP) following the immunisation campaign. Shulman and colleagues (2000) have isolated an unusual, highly diverged derivative of the Sabin PV type 2 strain from environmental samples during routine screening for wild-type PV in Israel. The extensive genetic divergence of the isolate from its parental Sabin PV type 2 strain suggested that the virus had replicated in one or more individuals for approximately 6 years (Shulman et al., 2000). According to other studies, VDPVs (with 1.4\% nucleotide divergence from the vaccine strain) were isolated from sewage and river water in Japan within 3 months following OPV vaccination, and several of these VDPV type 1 and 3 isolates showed increased neurovirulence (Horie et al., 2002; Yoshida et al., 2002). More recently, a highly evolved VDPV type 3 strain harbouring a 13\% sequence drift from Sabin PV type 3 vaccine strain has been isolated from sewage in Estonia (Blomqvist et al., 2004).

Vaccine strains of PV isolated from the environment have been found to be genetically and epidemiologically related to those circulating in the community (Divizia et al., 1999; Shulman et al., 2000). The properties of vaccine PV isolates from sewage and river water would reflect those of strains excreted by humans after OPV immunisation (Yoshida et 
al., 2002). These VDPVs may potentially cause poliomyelitis or related illness in susceptible individuals (Yoshida et al., 2002; Buttinelli et al., 2003). Thus, the presence in the environment of highly evolved, neurovirulent VDPV strains in the absence of polio cases would have important implications for strategies to terminate immunisation with OPV following global polio eradication.

This study addressed some of the issues regarding the evolution and nucleotide divergence of OPV strains isolated from selected sewage and river water samples in South Africa. Genotyping of the 5'UTR and VP1 regions of these OPV isolates using various molecular techniques demonstrated the prevalence of "suspected" VDPVs in the environment and the potential health risk they might constitute after termination of OPV immunisation in the near future.

\section{Materials and methods}

\subsection{Virus stock and cell cultures}

PV controls included: PV type 1, 2 and 3 vaccine strains, which were clinical isolates obtained from the National Institute of Virology (NIV), Johannesburg, South Africa. These PVs were recovered in BGM (buffalo green monkey kidney) (Code ECACC 90092601, passage 80-95), HEp-2 (human epidermoid carcinoma) (Code ATCC CCL23, passage 350-365) and PLC/PRF/5 (primary liver carcinoma) (Code ATCC 8024, passage 90-105) cell lines. The cell cultures were frozen and thawed three times, after demonstrating a cytopathogenic effect $(\mathrm{CPE})$. The debris was removed by centrifugation at $600 \times g$ (Eppendorf Centrifuge 5402D, Hamburg, Germany) for $10 \mathrm{~min}$ at room temperature $\left( \pm 25^{\circ} \mathrm{C}\right)$. The PV suspensions were stored at $-70{ }^{\circ} \mathrm{C}$ for further analysis.

\subsection{Isolation of polioviruses from sewage and river water}

During 2001 and 2003, 213 sewage samples were obtained from the Daspoort Sewage Treatment Plant, Pretoria and from the East Rand Water Care Company, Johannesburg, South Africa. Together these plants treat domestic and industrial sewage for approximately 3500000 people (Table 1). During the same period of time, a total of 138 river water samples (occasionally used by the rural community for domestic purposes) were obtained from selected rural areas in South Africa. The environmental samples were collected in $1 \mathrm{~L}$ sterile flasks from the sewage and river water sources. As a next step, the sewage and river water samples were decontaminated using chloroform (Merck, Darmstadt, Germany). Ten millilitres of chloroform were added to $50 \mathrm{ml}$ of sewage/river water samples and mixed for $30 \mathrm{~min}$ in a shaking incubator (Labcon, Labotec, South Africa) at $200 \mathrm{rpm}\left( \pm 25^{\circ} \mathrm{C}\right)$. The samples were centrifuged at $4500 \times g$ (Sorvall Super T 21 , Wilmington, USA) at $4{ }^{\circ} \mathrm{C}$ for $10 \mathrm{~min}$ in order to separate the supernatant from the chloroform (Merck). Viruses were recovered from these samples using the polyethylene glycol (PEG)/NaCl precipitation method (PEG 6000, Merck) (Minor, 1985). The resulting pellet was re-suspended in $10 \mathrm{ml}$ phosphate-buffered saline (PBS) (Sigma Chemical Co., Louis, USA) and inoculated onto BGM, HEp-2 and PLC/PRF/5 cell monolayers. Plaque assays were carried out for the detection of PVs using $92 \mathrm{~mm}$ 
Nunclon tissue culture plates (Nalge Nunc, Denmark) containing pre-formed monolayers of BGM, HEp- 2 and PLC/PRF/5 cells at a concentration of $2.0 \times 10^{5}$ cells ml $^{-1}$ (Manor et al., 1999). The incubation period for the plaque assay was between 5 and 7 days. The viruses from 10 well-separated plaques were picked for further propagation on BGM, HEp-2 and PLC/PRF/5 cell cultures, and were incubated for $72 \mathrm{~h}$.

Table 1.

Types of sewage samples used in the isolation of polioviruses from selected water treatment plants in South Africa

\begin{tabular}{|c|c|c|c|c|}
\hline System & Dessgn & & & \\
\hline 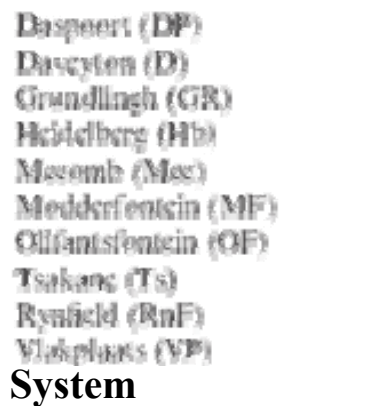 & 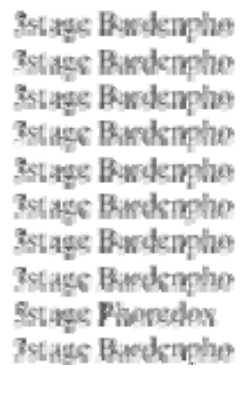 & Design & Waste type & $\begin{array}{l}\text { Popula- } \\
\text { tion size }\end{array}$ \\
\hline Daspoort (DP) & & $\begin{array}{l}\text { 3stage } \\
\text { Bardenpho }\end{array}$ & $100 \%$ domestic & 200000 \\
\hline Daveyton (D) & & $\begin{array}{l}\text { 3stage } \\
\text { Bardenpho }\end{array}$ & $100 \%$ domestic & 13000 \\
\hline Grundlingh (GR) & & $\begin{array}{l}\text { 3stage } \\
\text { Bardenpho }\end{array}$ & $\begin{array}{l}60 \% \text { domestic and } 40 \% \\
\text { industrial }\end{array}$ & 5000 \\
\hline Heidelberg $(\mathrm{Hb})$ & & $\begin{array}{l}\text { 3stage } \\
\text { Bardenpho }\end{array}$ & $\begin{array}{l}70 \% \text { domestic and } 30 \% \\
\text { Industrial }\end{array}$ & 10000 \\
\hline Mccomb (Mcc) & & $\begin{array}{l}\text { 3stage } \\
\text { Bardenpho }\end{array}$ & $100 \%$ industrial & 5000 \\
\hline Modderfontein (MF) & & $\begin{array}{l}\text { 3stage } \\
\text { Bardenpho }\end{array}$ & $\begin{array}{l}40 \% \text { domestic and } 60 \% \\
\text { Industrial }\end{array}$ & 3000 \\
\hline Olifantsfontein (OF) & & $\begin{array}{l}\text { 3stage } \\
\text { Bardenpho }\end{array}$ & $\begin{array}{l}60 \% \text { domestic and } 40 \% \\
\text { Industrial }\end{array}$ & 100000 \\
\hline Tsakane (Ts) & & $\begin{array}{l}\text { 3stage } \\
\text { Bardenpho }\end{array}$ & $100 \%$ domestic & 20000 \\
\hline Rynfield (RnF) & & $\begin{array}{l}\text { 5stage } \\
\text { Phoredox }\end{array}$ & $100 \%$ domestic & 20000 \\
\hline Vlakplaats (VP) & & $\begin{array}{l}\text { 3stage } \\
\text { Bardenpho }\end{array}$ & $\begin{array}{l}70 \% \text { domestic and } 30 \% \\
\text { industrial }\end{array}$ & 130000 \\
\hline
\end{tabular}




\subsection{Ribonucleic acid extraction and primary molecular characterisation of virus isolates}

Ribonucleic acid (RNA) was extracted from infected cell culture fluid by means of a commercial RNeasy Mini Kit (Qiagen, Hilden, Germany) according to the manufacturer's instructions. The RNase-Free DNase kit (Qiagen) provided efficient on-column digestion of deoxyribonucleic acid (DNA) during RNA purification from cells. A reverse transcription multiplex PCR (RT-multiplex PCR) as described by Egger et al. (1995) was used for the rapid detection of PVs and for their distinction from non-polio enteroviruses (NPEVs). Primers specific for either enterovirus (EV) or PV were combined in a RTmultiplex PCR (Promega Access RT-PCR system, Promega Corp., Madison, USA) and gave rise to amplicons of different sizes (Table 2). Optimised final concentrations in a total volume of $50 \mu \mathrm{l}$ were as follows: AMV/Tfl reaction buffer $(1 \mathrm{x}), 2.0 \mathrm{mM} \mathrm{MgSO}_{4}$, dNTP Mix (final concentration of $0.2 \mathrm{mM}$ ), 25 pmol each of primers E1, E2, Po1, Po2, Po3 and Po4 (Sigma-Genosys Ltd., Pampisford, Cambridgeshire, UK), and 5 U each of AMV reverse transcriptase and TfI DNA polymerase (Promega Corp.). The PCR conditions included: reverse transcription for $45 \mathrm{~min}$ at $48^{\circ} \mathrm{C}$, \{DNA denaturation for $1 \mathrm{~min}$ at $94{ }^{\circ} \mathrm{C}$, primer annealing for $1.5 \mathrm{~min}$ at $45^{\circ} \mathrm{C}$ and primer extension for $1 \mathrm{~min}$ at $\left.72{ }^{\circ} \mathrm{C}\right\} 30$ cycles and final extension for $10 \mathrm{~min}$ at $72{ }^{\circ} \mathrm{C}$ (Hybaid OmniGene Thermocycler, United Kingdom). After 30 cycles, $20 \mu \mathrm{l}$ of each PCR product were subjected to agarose (2\%) (Seakem LE agarose, Bioproducts, USA) gel electrophoresis (Midicell Primo Gel Apparatus, Holbrook, New York, USA).

\section{Table 2.}

Enterovirus and poliovirus specific primers ${ }^{\mathrm{a}}$ used in the RT-multiplex PCR (Egger et al., 1995)

\begin{tabular}{|c|c|c|c|c|}
\hline $\begin{array}{l}\text { Primer } \\
\text { region } \\
\text { and map } \\
\text { position }\end{array}$ & $\begin{array}{l}\text { Prim } \\
\text { er }\end{array}$ & Sequence $^{c}$ & $\begin{array}{l}\text { Amplic } \\
\text { on } \\
\text { length } \\
\text { (bp) }\end{array}$ & $\begin{array}{l}\text { Specifi } \\
\text { city }\end{array}$ \\
\hline \multicolumn{5}{|l|}{ 5'UTR } \\
\hline $163-178$ & E1 & 5'-AAG CAC TTC TGT TTC C-3' & 297 & $\mathrm{EV}$ \\
\hline $443-460$ & E2 & 5'-CAT TCA GGG GCC GGA GGA-3' & & $\mathrm{EV}$ \\
\hline \multicolumn{5}{|l|}{$\mathrm{P} 2$ region } \\
\hline $\begin{array}{l}4460- \\
4478\end{array}$ & Po1 & 5'-CAG TTC AAG AGC AA $(\underline{\mathrm{A}} / \mathrm{G})$ CAC C-3' & 193 & PV \\
\hline $4634-$ & Po2 & 5'-TC $(\mathrm{A} / \underline{\mathrm{G}})$ TCC AT $(\underline{\mathrm{A}} / \mathrm{G})$ AT $(\mathrm{A} / \underline{\mathrm{C}})$ AC $(\mathrm{T} / \underline{\mathrm{C}})$ & & PV \\
\hline
\end{tabular}




\begin{tabular}{|l|l|l|l|l|}
\hline $\begin{array}{l}\text { Primer } \\
\text { region } \\
\text { and map } \\
\text { position }\end{array}$ & $\begin{array}{l}\text { Prim } \\
\text { er }\end{array}$ & Sequence $^{\mathbf{c}}$ & $\begin{array}{l}\text { Amplic } \\
\text { on } \\
\text { length } \\
\text { (bp) }\end{array}$ & $\begin{array}{l}\text { Specifi } \\
\text { city }\end{array}$ \\
\hline 4653 & & AC (T/A) CC-3' & & \\
\hline $\begin{array}{l}\text { P2-P3 } \\
\text { region }\end{array}$ & & & & \\
\hline $\begin{array}{l}4922- \\
4941\end{array}$ & Po3 & 5'-GAA ATG TGT AAG AAC TGT CA-3' $^{\prime}$ & 565 & PV \\
\hline $\begin{array}{l}5467- \\
5487\end{array}$ & Po4 & 5'-GTA ACA ATG TTT CTT TTA GCC-3' $^{\prime}$ & & PV \\
\hline
\end{tabular}

${ }^{a}$ Primers E1 and E2 were described previously (Hyypiä et al., 1989).

${ }^{\mathrm{b}}$ Map position and sequence of PV type 1 (Sabin) are given.

${ }^{c}$ For the degenerate primers Po1 and Po2, the sequence of the Sabin strain is underlined.

\subsection{Sabin specific RT-triplex PCR}

Three sets of primers specific for Sabin PV type 1, 2 and 3 were combined in a RTtriplex PCR to confirm the isolated PVs as Sabin vaccine strains and gave rise to amplicons of different sizes (Table 3) (Yang et al., 1991 and Yang et al., 1992; Chezzi, 1996). A $50 \mu \mathrm{l}$ reaction volume was prepared using: AMV/Tfl reaction buffer $(1 x)$, dNTP Mix (final concentration of $0.2 \mathrm{mM}$ ), 25 pmol each of primers S1-1, S1-2, S2-1, S2-2, S3-1a, S3-2 (Sigma-Genosys), $1.5 \mathrm{mM}$ of $\mathrm{MgSO}_{4}$, and $5 \mathrm{U}$ each of AMV reverse transcriptase and Tfl DNA polymerase (Promega Corp.). The PCR conditions included: reverse transcription for $45 \mathrm{~min}$ at $42{ }^{\circ} \mathrm{C}$, \{DNA denaturation for $30 \mathrm{~s}$ at $95{ }^{\circ} \mathrm{C}$, primer annealing for $45 \mathrm{~s}$ at $56^{\circ} \mathrm{C}$ and primer extension for $1 \mathrm{~min}$ at $72{ }^{\circ} \mathrm{C}$ \} 30 cycles and final extension for $10 \mathrm{~min}$ at $72{ }^{\circ} \mathrm{C}$ (Hybaid OmniGene Thermocycler). The amplified products $(20 \mu \mathrm{l})$ were separated using $7 \%$ polyacrylamide (BioRad, Hercules, California, USA) gel electrophoresis using a Hoefer electrophoresis unit at $120 \mathrm{~V}$ (Hoefer, San Francisco, USA). 
Table 3.

Sabin specific RT-PCR primers used in the detection and differentiation of Sabin PV types 1, 2 and 3 (Yang et al., 1991 and Yang et al., 1992)

\begin{tabular}{|l|l|l|l|l|}
\hline $\begin{array}{l}\text { Primer } \\
\text { region }\end{array}$ & $\begin{array}{l}\text { Pri- } \\
\text { mer }\end{array}$ & Sequence & $\begin{array}{l}\text { Ampli- } \\
\text { con } \\
\text { length } \\
\text { (bp) }\end{array}$ & Specificity \\
\hline $2584-2601$ & S1-1 & $5^{\prime}$-TCC ACT GGC TTC AGT GTT-3' & 97 & Sabin PV type 1 \\
\hline $2505-2523$ & S1-2 & $5^{\prime}$-AGG TCA GAT GCT TGA AAG C-3' & & \\
\hline $2580-2595$ & S2-1 & $5^{\prime}$-CGG CTT GTG TCC AGG C-3' & 71 & Sabin PV type 2 \\
\hline $2525-2544$ & S2-2 & $5^{\prime}$-CCG TTG AAG GGA TTA CTA AA-3' & & \\
\hline & S3-1a & $5^{\prime}$-AGT ATC AGG TAA GCT ATC C-3' & 54 & Sabin PV type 3 \\
\hline $2537-2553$ & S3-2 & $5^{\prime}$-AGG GCG CCC TAA CTT TG-3' & & \\
\hline
\end{tabular}

\subsection{RT-PCR amplification of the 5'untranslated region of polioviruses}

The 5'untranslated region (5'UTR) of the PV genome was subjected to RT-PCR amplification as described by Divizia et al. (1999) and Guillot et al. (2000) with a few modifications. The primers used for the 5'UTR were as follows: UG52 (nt 160-180) and UC53 (nt 599-580) (Sigma-Genosys) (Table 4). Optimised final concentrations in a total volume of $50 \mu \mathrm{l}$ included: AMV/Tfl reaction buffer $(1 x), 2.0 \mathrm{mM} \mathrm{MgSO}_{4}$, dNTP mix (final concentration of $0.2 \mathrm{mM}$ ), $10 \mathrm{pmol}$ each of primers UG52 and UC53, $5 \mathrm{U}$ each of AMV reverse transcriptase and TfI DNA polymerase (Promega Corp.). The PCR conditions included: reverse transcription for $45 \mathrm{~min}$ at $42{ }^{\circ} \mathrm{C}$, \{DNA denaturation for $30 \mathrm{~s}$ at $95^{\circ} \mathrm{C}$, primer annealing for $45 \mathrm{~s}$ at $45^{\circ} \mathrm{C}$ and primer extension for $1 \mathrm{~min}$ at $\left.72{ }^{\circ} \mathrm{C}\right\} 30$ cycles and final extension for $10 \mathrm{~min}$ at $72{ }^{\circ} \mathrm{C}$ (Hybaid OmniGene Thermocycler). After 30 cycles, $20 \mu \mathrm{l}$ of each PCR product were subjected to agarose (2\%) (Seakem) gel electrophoresis (Midicell Primo Gel Apparatus). 
Table 4.

Primers used in the RT-PCRs for the amplification of the 5'UTR and VP1 region of the poliovirus genome (Divizia et al., 1999; Guillot et al., 2000)

\begin{tabular}{|c|c|c|c|}
\hline $\begin{array}{l}\text { Primer } \\
\text { region }\end{array}$ & Primer & Sequence & $\begin{array}{l}\text { Amplicon } \\
\text { length (bp) }\end{array}$ \\
\hline \multicolumn{4}{|l|}{$5^{\prime} \mathrm{UTR}$} \\
\hline $160-180$ & UG52 & 5'-AAC AAG CAC TTC TGT TTC CCC-3' & 440 \\
\hline $580-599$ & UC53 & 5'-GTG ATT GTC ACC ATA AGC AG-3' & \\
\hline \multicolumn{4}{|l|}{ VP1 } \\
\hline $2402-2422$ & UG1 & 5'-TTT GTG TCA GCG TGT AAT GAC-3' & 480 \\
\hline $2862-2881$ & $\mathrm{UC} 1$ & 5'-AAA ${ }^{\text {a }}$ TTC CAT ATC AAA TCT AG-3' & \\
\hline \multicolumn{4}{|l|}{ VP1 } \\
\hline $2426-2446$ & N2426 & 5'-AGC GTG CGC TTG ATG CGA GAT-3' & 387 \\
\hline $2792-2812$ & N2812 & 5'-AGT GAT CTT CCA CAC TGT ${ }^{\mathrm{b}}$ AAA-3' & \\
\hline
\end{tabular}

${ }^{\text {a }}$ For Mahoney poliovirus type 1 there is a G, instead of an A in the VP1 genome.

${ }^{\mathrm{b}}$ Mahoney poliovirus type 1 there is a $\mathrm{C}$, instead of a T in the VP1 genome.

\subsection{RT-PCR amplification of the vp1 capsid protein of polioviruses}

The virus protein (VP1) region of the PV genome was subjected to RT-PCR amplification as described by Divizia et al. (1999) and Guillot et al. (2000) with a few modifications. The primers used for the VP1 region were as follows: UG1 (nt 24022422) and UC1 (nt 2881-2861) (Sigma-Genosys) (Table 4). Optimised final concentrations in a total volume of $50 \mu \mathrm{l}$ were: AMV/Tfl reaction buffer $(1 x), 2.0 \mathrm{mM}$ $\mathrm{MgSO}_{4}, \mathrm{dNTP} \operatorname{mix}$ (final concentration of $0.2 \mathrm{mM}$ ), 10 pmol each of primers UG1 and $\mathrm{UC1}, 5 \mathrm{U}$ each of AMV reverse transcriptase and Tfl DNA polymerase (Promega Corp.). The PCR conditions were as follows: reverse transcription for $45 \mathrm{~min}$ at $42{ }^{\circ} \mathrm{C}$, [DNA denaturation for $30 \mathrm{~s}$ at $95^{\circ} \mathrm{C}$, primer annealing for $45 \mathrm{~s}$ at $50{ }^{\circ} \mathrm{C}$ and primer extension for $1 \mathrm{~min}$ at $72{ }^{\circ} \mathrm{C}$ \} 30 cycles and final extension for $10 \mathrm{~min}$ at $72{ }^{\circ} \mathrm{C}$ (Hybaid OmniGene Thermocycler). After 30 cycles, $20 \mu \mathrm{l}$ of each PCR product were subjected to agarose (2\%) (Seakem) gel electrophoresis (Midicell Primo Gel Apparatus).

A nested PCR was performed as described by Divizia et al. (1999) immediately after completion of the RT-PCR step. The primers used for the nested PCR were as follows: 
N2426 (nt 2426-2446) and N2812 (nt 2812-2792) (Sigma-Genosys) (Table 4). The nested PCR mixture contained the following: $1 x$ PCR buffer $(10 \mathrm{mM}$ tris-HCl, $\mathrm{pH}$; $50 \mathrm{mM} \mathrm{KCl} ; 0.1 \%$ Triton $\mathrm{X}-100$ ), $\mathrm{MgCl}_{2}$ (final concentration of $1.5 \mathrm{mM}$ ), dNTP mix (final concentration of $0.2 \mathrm{mM}$ ), primers N2426 and N2812 (10 pmol each) and $1.5 \mathrm{U}$ of Taq DNA polymerase (Promega Corp.). The nested PCR conditions were as follows: DNA denaturation for $2 \mathrm{~min}$ at $94^{\circ} \mathrm{C}$, \{DNA denaturation for $1 \mathrm{~min}$ at $94{ }^{\circ} \mathrm{C}$, primer annealing for $1 \mathrm{~min}$ at $45^{\circ} \mathrm{C}$ and primer extension for $1 \mathrm{~min}$ at $72^{\circ} \mathrm{C}$ \} 30 cycles and final extension for $10 \mathrm{~min}$ at $72{ }^{\circ} \mathrm{C}$ (Hybaid OmniGene Thermocycler). After 30 cycles, $20 \mu 1$ of each nested PCR product were subjected to agarose (2\%) (Seakem) gel electrophoresis (midicell primo gel apparatus).

\subsection{Nucleotide sequencing and phylogenetic analysis}

Before initiating sequencing, the exconuclease I/Shrimp alkaline phosphatase (Fermentas, Vilnus, Lithuania) was used to clean the PCR samples from primers and nucleotides (Inqaba Biotechnical Industries (Pty) Ltd, Pretoria, South Africa). The ABI BigDye Terminator cycle sequencing kit version 3.1 was used to sequence the PCR products (Inqaba Biotechnical Industries). In the latter procedure, approximately $500 \mathrm{ng}$ of PCR products were employed in the sequencing reaction (Inqaba Biotechnical Industries). Both strands of the amplified fragments were sequenced to confirm the nature of the product obtained (Inqaba Biotechnical Industries). The data was analysed on a Spectrumedix SCE2410 genetic analysis system (Inqaba Biotechnical Industries).

The sequences of the PV genomes described in this study were compared with parameters from the European Bioinformatics Institute (EMBL) database by using the FASTA program and were submitted via the internet to GenBank database. Multiple sequence alignments were performed by the ClustalX program (Higgins and Sharp, 1988). Phylogenetic trees were constructed using the maximum-likelihood analysis programs PHYLIP (version 3.57c) and PUZZLE (version 4.0), and were visualised using NJPLOT (Felsenstein, 1981). Bootstrap analysis of the 5'UTR and VP1 nucleotide sequences were performed with the SEQBOOT program of the PHYLIP package with 1000 replicates. Nucleotide sequence comparisons were made with previously published sequences (GenBank accession numbers: AY177685AY177685, AY184219AY184219, AY184220AY184220, AY184221AY184221, PI3L37PI3L37, POL430385POL430385, V01149V01149).

\subsection{Nucleotide sequence accession numbers}

The sequences of the 5'UTR and the VP1 of PVs isolated from sewage and river water in South Africa described in this study have been deposited in the GenBank data library. Accession numbers have been assigned to all of the PV isolates (Table 5). 
Table 5.

Extent of nucleotide divergence between the characterised 5'UTR and VP1 regions of polioviruses isolated in this study from their attenuated parental Sabin poliovirus vaccine strains

\begin{tabular}{|c|c|c|c|c|c|}
\hline $\begin{array}{l}\% \\
\text { Differe } \\
\text { nce in } \\
\text { the } \\
5^{\prime} \text { UTR }\end{array}$ & $\begin{array}{l}\text { Accession } \\
\text { number for } \\
\text { the 5'UTR } \\
\text { region }\end{array}$ & Sample & $\begin{array}{l}\text { Type } \\
\text { of } \\
\text { virus }\end{array}$ & $\begin{array}{l}\text { Accession } \\
\text { number for } \\
\text { the VP1 } \\
\text { region }\end{array}$ & $\begin{array}{l}\% \\
\text { Differe } \\
\text { nce in } \\
\text { the } \\
\text { VP1 }\end{array}$ \\
\hline 0.3 & $\begin{array}{l}\text { AJ783729AJ7 } \\
83729\end{array}$ & $\begin{array}{l}\text { DP1 (Daspoort sewage) } \\
(13 / 09 / 2001)\end{array}$ & PV1 & $\begin{array}{l}\text { AJ783857AJ7 } \\
83857\end{array}$ & 0.8 \\
\hline 0.3 & $\begin{array}{l}\text { AJ783732AJ7 } \\
83732\end{array}$ & $\begin{array}{l}\text { Kspnt DR (river water) } \\
(15 / 04 / 2002)\end{array}$ & PV1 & $\begin{array}{l}\text { AJ783810AJ7 } \\
83810\end{array}$ & 0.8 \\
\hline 0.3 & $\begin{array}{l}\text { AJ635236AJ6 } \\
35236\end{array}$ & $\begin{array}{l}\text { OF1 (Olifantsfontein } \\
\text { sewage) }(21 / 05 / 2002)\end{array}$ & PV1 & $\begin{array}{l}\text { AJ635237AJ6 } \\
35237\end{array}$ & 0.9 \\
\hline 0 & $\begin{array}{l}\text { AJ783727AJ7 } \\
83727\end{array}$ & $\begin{array}{l}\text { Ts1 (Tsakane sewage) } \\
(11 / 09 / 2002)\end{array}$ & PV1 & $\begin{array}{l}\text { AJ783847AJ7 } \\
83847\end{array}$ & 0 \\
\hline 0.3 & $\begin{array}{l}\text { AJ783726AJ7 } \\
83726\end{array}$ & $\begin{array}{l}\text { RnF2 (Rynfield sewage) } \\
(17 / 09 / 2002)\end{array}$ & PV1 & $\begin{array}{l}\text { AJ783848AJ7 } \\
83848\end{array}$ & 0 \\
\hline 0.3 & $\begin{array}{l}\text { AJ783724AJ7 } \\
83724\end{array}$ & $\begin{array}{l}\text { MF3 (Modderfontein } \\
\text { sewage) }(08 / 10 / 2002)\end{array}$ & PV1 & $\begin{array}{l}\text { AJ783853AJ7 } \\
83853\end{array}$ & 0.6 \\
\hline 0.3 & $\begin{array}{l}\text { AJ783722AJ7 } \\
83722\end{array}$ & $\begin{array}{l}\text { D2 (Daveyton sewage) } \\
(08 / 10 / 2002)\end{array}$ & PV1 & $\begin{array}{l}\text { AJ783858AJ7 } \\
83858\end{array}$ & 0.8 \\
\hline 0.3 & $\begin{array}{l}\text { AJ783723AJ7 } \\
83723\end{array}$ & $\begin{array}{l}\text { Mcc4 (Mccomb sewage) } \\
(08 / 10 / 2002)\end{array}$ & PV1 & $\begin{array}{l}\text { AJ783856AJ7 } \\
83856\end{array}$ & 0.6 \\
\hline 0 & $\begin{array}{l}\text { AJ783725AJ7 } \\
83725\end{array}$ & $\begin{array}{l}\text { Mcc1 (Mccomb sewage) } \\
(22 / 10 / 2002)\end{array}$ & PV1 & $\begin{array}{l}\text { AJ783855AJ7 } \\
83855\end{array}$ & 0.5 \\
\hline 0 & $\begin{array}{l}\text { AJ783728AJ7 } \\
83728\end{array}$ & $\begin{array}{l}\text { Sbnd2 (river water) } \\
(09 / 01 / 2003)\end{array}$ & PV1 & $\begin{array}{l}\text { AJ783806AJ7 } \\
83806\end{array}$ & 0 \\
\hline 0 & $\begin{array}{l}\text { AJ783730AJ7 } \\
83730\end{array}$ & $\begin{array}{l}\text { Lv1 (river water) } \\
(09 / 01 / 2003)\end{array}$ & PV1 & $\begin{array}{l}\text { AJ783808AJ7 } \\
83808\end{array}$ & 0 \\
\hline 0 & $\begin{array}{l}\text { AJ783731AJ7 } \\
83731\end{array}$ & $\begin{array}{l}\text { Mb1 (river water) } \\
(15 / 04 / 2003)\end{array}$ & PV1 & $\begin{array}{l}\text { AJ783809AJ7 } \\
83809\end{array}$ & 0 \\
\hline 0.7 & AJ783721AJ7 & Sbnd1 (river water) & PV1 & AJ783805AJ7 & 0.6 \\
\hline
\end{tabular}




\begin{tabular}{|c|c|c|c|c|c|}
\hline $\begin{array}{l}\% \\
\text { Differe } \\
\text { nce in } \\
\text { the } \\
5^{\prime} \text { UTR }\end{array}$ & $\begin{array}{l}\text { Accession } \\
\text { number for } \\
\text { the 5'UTR } \\
\text { region }\end{array}$ & Sample & $\begin{array}{l}\text { Type } \\
\text { of } \\
\text { virus }\end{array}$ & $\begin{array}{l}\text { Accession } \\
\text { number for } \\
\text { the VP1 } \\
\text { region }\end{array}$ & $\begin{array}{l}\% \\
\text { Differe } \\
\text { nce in } \\
\text { the } \\
\text { VP1 }\end{array}$ \\
\hline & 83721 & $(15 / 04 / 2003)$ & & 83805 & \\
\hline 0.5 & $\begin{array}{l}\text { AJ783737AJ7 } \\
83737\end{array}$ & $\begin{array}{l}\text { OF2 (Olifantsfontein } \\
\text { sewage) }(21 / 05 / 2002)\end{array}$ & PV2 & $\begin{array}{l}\text { AJ783813AJ7 } \\
83813\end{array}$ & 0.7 \\
\hline 0.5 & $\begin{array}{l}\text { AJ783720AJ7 } \\
83720\end{array}$ & $\begin{array}{l}\text { OF2 (Olifantsfontein } \\
\text { sewage) }(28 / 05 / 2002)\end{array}$ & PV2 & $\begin{array}{l}\text { AJ783804AJ7 } \\
83804\end{array}$ & 0.2 \\
\hline 0.9 & $\begin{array}{l}\text { AJ783735AJ7 } \\
83735\end{array}$ & $\begin{array}{l}\text { OF2 (Olifantsfontein } \\
\text { sewage) }(02 / 07 / 2002)\end{array}$ & PV2 & $\begin{array}{l}\text { AJ783859AJ7 } \\
83859\end{array}$ & 0.2 \\
\hline 0.5 & $\begin{array}{l}\text { AJ783736AJ7 } \\
83736\end{array}$ & $\begin{array}{l}\text { TCspntDR (river water) } \\
(16 / 07 / 2002)\end{array}$ & PV2 & $\begin{array}{l}\text { AJ783811AJ7 } \\
83811\end{array}$ & 0 \\
\hline 0.5 & $\begin{array}{l}\text { AJ783733AJ7 } \\
83733\end{array}$ & $\begin{array}{l}\text { D1 (Daveyton sewage) } \\
\text { (28/08/2002) }\end{array}$ & PV2 & $\begin{array}{l}\text { AJ783852AJ7 } \\
83852\end{array}$ & 1.4 \\
\hline 0.5 & $\begin{array}{l}\text { AJ783734AJ7 } \\
83734\end{array}$ & $\begin{array}{l}\text { Mt2 (river water) } \\
(15 / 04 / 2003)\end{array}$ & PV2 & $\begin{array}{l}\text { AJ783807AJ7 } \\
83807\end{array}$ & 0.2 \\
\hline 0.5 & $\begin{array}{l}\text { AJ783774AJ7 } \\
83774\end{array}$ & $\begin{array}{l}\text { DP1 (Daspoort sewage) } \\
(13 / 08 / 2001)\end{array}$ & PV3 & $\begin{array}{l}\text { AJ783812AJ7 } \\
83812\end{array}$ & 0.2 \\
\hline 0.5 & $\begin{array}{l}\text { AJ783770AJ7 } \\
83770\end{array}$ & $\begin{array}{l}\text { VP1 (Vlaakplats sewage) } \\
(09 / 07 / 2002)\end{array}$ & PV3 & $\begin{array}{l}\text { AJ783854AJ7 } \\
83854\end{array}$ & 0.2 \\
\hline 0.5 & $\begin{array}{l}\text { AJ783739AJ7 } \\
83739\end{array}$ & $\begin{array}{l}\text { MF1 (Modderfontein } \\
\text { sewage) }(23 / 07 / 2002)\end{array}$ & PV3 & $\begin{array}{l}\text { AJ783815AJ7 } \\
83815\end{array}$ & 0.2 \\
\hline 0.5 & $\begin{array}{l}\text { AJ783772AJ7 } \\
83772\end{array}$ & $\begin{array}{l}\text { GR2 (Grundlingh sewage) } \\
(23 / 07 / 2002)\end{array}$ & PV3 & $\begin{array}{l}\text { AJ783850AJ7 } \\
83850\end{array}$ & 0.2 \\
\hline 0.5 & $\begin{array}{l}\text { AJ783773AJ7 } \\
83773\end{array}$ & $\begin{array}{l}\text { OF5 (Olifantsfontein } \\
\text { sewage) }(23 / 07 / 2002)\end{array}$ & PV3 & $\begin{array}{l}\text { AJ783849AJ7 } \\
83849\end{array}$ & 0.2 \\
\hline 0.5 & $\begin{array}{l}\text { AJ783738AJ7 } \\
83738\end{array}$ & $\begin{array}{l}\text { Hb1 (Heidelberg sewage) } \\
\text { (11/09/2002) }\end{array}$ & PV3 & $\begin{array}{l}\text { AJ783814AJ7 } \\
83814\end{array}$ & 0.2 \\
\hline 0.5 & $\begin{array}{l}\text { AJ783771AJ7 } \\
83771\end{array}$ & $\begin{array}{l}\text { D9 (Daveyton sewage) } \\
(08 / 10 / 2002)\end{array}$ & PV3 & $\begin{array}{l}\text { AJ783851AJ7 } \\
83851\end{array}$ & 0.2 \\
\hline
\end{tabular}




\section{Results and discussion}

Using the monolayer plaque assay, 703 plaques from sewage and 157 plaques from river water samples were analysed. Application of the RT-multiplex PCR revealed that 176 of these plaques were NPEVs, and 49 were PV isolates. The remaining 634 plaques might possibly have been reoviruses or adenoviruses, since the HEp-2 cell line was applied in this assay. However, these plaques were not subjected to further analysis. The Sabin specific RT-triplex PCR showed that all $49 \mathrm{PV}$ isolates were vaccine strains consisting of 29 Sabin PV type 1 (59.2\%), 8 Sabin PV type 2 (16.3\%) and 12 Sabin PV type 3 (24.5\%) isolates. No wild-type PVs were detected in the sewage and river water samples, which was in agreement with epidemiological data indicating that poliomyelitis has been eradicated in South Africa (Centers for Disease Control and Prevention [CDC], 2003).

A representative number of PVs (26 from the initial 49 PVs) isolated from sewage and river water samples were selected for sequencing analysis of the 5'UTR and VP1 regions. The total number of PVs sequenced included: 13 PVs type 1, 7 PVs type 3 and 6 PVs type 2 .

\subsection{Phylogenetic analysis of the 5'UTR of the poliovirus genome}

The unrooted phylogenetic tree, resulting from comparison of the 5'UTR nucleotide sequences of the PVs isolated from selected sewage and river water samples in this study, consisted of three main groups (Fig. 1). In Group 1, five PV type 1 isolates (AJ783725AJ783725, AJ783727AJ783727, AJ783728AJ783728, AJ783730AJ783730 and AJ783731AJ783731) displayed 100\% nucleotide sequence identity to the attenuated Sabin PV type 1 (AY184219AY184219) reference strain (Table 5). Seven PV type 1 isolates (AJ635236AJ635236, AJ783722AJ783722, AJ783723AJ783723, AJ783724AJ783724, AJ783726AJ783726, AJ783729AJ783729, AJ783732AJ783732) shared $100 \%$ nucleotide sequence identity with the neurovirulent reference strain PV type 1 Mahoney (V01149V01149) and 99.7\% similarity to the attenuated (AY184219AY184219) reference strain. Isolate AJ783721 showed 99.3\% identity to the AY184219AY184219 reference strain. In addition, isolate AJ783721AJ783721 and the subgroup of V01149V01149 (AJ635236AJ635236, AJ783722AJ783722, AJ783723AJ783723, AJ783724AJ783724, AJ783726AJ783726, AJ783729AJ783729 and AJ783732AJ783732) had a mutation at position 480 in the 5'UTR, which involved a direct reversion of a $\mathrm{G}$ base (found in the attenuated Sabin strain) to A base (found in the virulent strain). This mutation is typically associated with reversion of the attenuated Sabin PV type 1 vaccine strain to increased neurovirulence (Minor, 1992 and Minor, 1999; Li et al., 1996; Georgescu et al., 1997; Martin and Minor, 2002). 


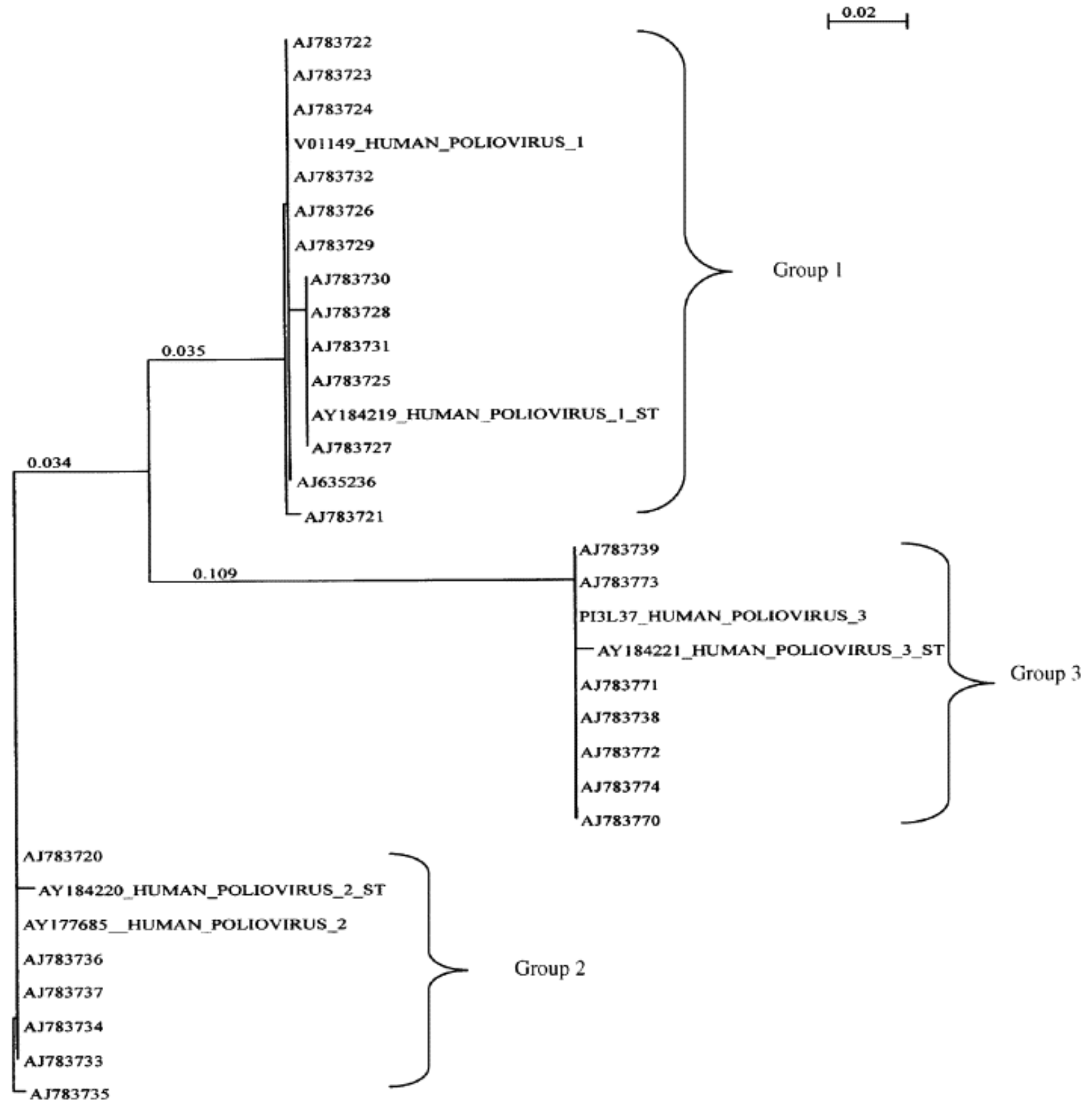

Fig. 1. Unrooted phylogenetic tree re-constructed with the neighbour-joining method from the comparative 5'untranslated region sequence analysis of the sewage isolated oral poliovirus vaccine strains and the poliovirus reference strains. Branch lengths are proportional to the phylogenetic distances, while the vertical branches are noninformative. The scale bar shows $2 \%$ nucleotide sequence difference. 
Group 2 consisted of PV type 2 isolates and two reference strains: the attenuated Sabin PV type 2 and PV type 2 strain (AY177685AY177685) (Fig. 1). The reference PV type 2 strain (AY177685AY177685) was isolated by Buttinelli et al. (2003) from an immunodeficient patient soon after the onset of paralysis. Even though the patient had permanent paralysis and mutations were present in positions 481 of the 5'UTR and 2908 of VP1 (amino acid 143), known to be correlated with the neurovirulent phenotype (Minor and Dunn, 1988; Equestre et al., 1991; Minor, 1999; Martin and Minor, 2002), the virus did not cause paralysis when tested in transgenic mouse strains (Buttinelli et al., 2003). Nonetheless, AY177685AY177685 was used as a reference PV type 2 strain, because most of the PV type 2 isolates in this study were to a certain extent genetically related to this virus. Five of the PV type 2 isolates in this study (AJ783720AJ783720, AJ783733AJ783733, AJ783734AJ783734, AJ783736AJ783736, AJ783737AJ783737) differed at $0.5 \%$ in 5 'UTR sequences from the attenuated AY184220AY184220 reference strain (Table 5). Isolate AJ783735AJ783735 showed a higher nucleotide sequence divergence $(0.9 \%)$ from the attenuated AY184220AY184220 reference strain. All PV type 2 isolates in this study had the key mutation at position 481 in the $5^{\prime}$ UTR (a conversion from A to a $\mathrm{G}$ base).

Group 3 was comprised of PV type 3 strains (Fig. 1). All PV type 3 isolates (AJ783738AJ783738, AJ783739AJ783739, AJ783770AJ783770, AJ783771AJ783771, AJ783772AJ783772, AJ783773AJ783773 and AJ783774AJ783774) displayed 100\% nucleotide sequence identity with the neurovirulent reference PV strain P3/Leon/37 (PI3L37PI3L37) (Table 5). In addition, these PV isolates diverged at $0.5 \%$ in 5 'UTR sequences from the attenuated reference strain Sabin PV type 3 (AY184221AY184221). All PV type 3 isolates (AJ783738AJ783738, AJ783739AJ783739, AJ783770AJ783770, AJ783771AJ783771, AJ783772AJ783772, AJ783773AJ783773, AJ783774AJ783774) displayed a mutation at position 472 in the 5'UTR, which involved reversion of an U base (found in the attenuated vaccine strain) to a $\mathrm{C}$ base (found in the virulent strain). This mutation is typically associated with reversion to neurovirulence in Sabin PV type 3 vaccine strains (Minor, 1992 and Minor, 1999; Martin and Minor, 2002).

\subsection{Phylogenetic analysis of the VP1 region of the poliovirus genome}

Three main groups were evident from the unrooted phylogenetic tree of the VP1 capsidencoding region of the PVs isolated in this study (Fig. 2). In Group 1, five of the PV type 1 isolates (AJ783806AJ783806, AJ783808AJ783808, AJ783809AJ783809, AJ783847AJ783847, AJ783848AJ783848), showed 100\% nucleotide sequence similarity with the attenuated Sabin PV type 1 (AY184219AY184219) reference strain (Table 5). However, these isolates differed from the Cox type 1 live-attenuated PV (POL430385POL430385) at 1.2\% and the virulent PV type 1 Mahoney (V01149V01149) at 2.2\% of VP1 nucleotides. Isolates AJ783855AJ783855, AJ783805AJ783805, AJ783853AJ783853 and AJ783856AJ783856 differed from the attenuated AY184219AY184219 reference strain by $>0.5 \%$ in VP1 nucleotides. High nucleotide divergences from the AY184219AY184219 strain (0.8\% in VP1 sequences) were observed for isolates (AJ783810AJ783810, AJ783857AJ783857, AJ783858AJ783858). Isolate AJ635237AJ635237 displayed the highest nucleotide divergence $(>0.9 \%)$ from 
the AY184219AY184219 reference strain. Although different mutations can be found in the VP1 genomes of PV type 1 isolates, none of these mutations have ever been implicated as major factors in changes of PV virulence.

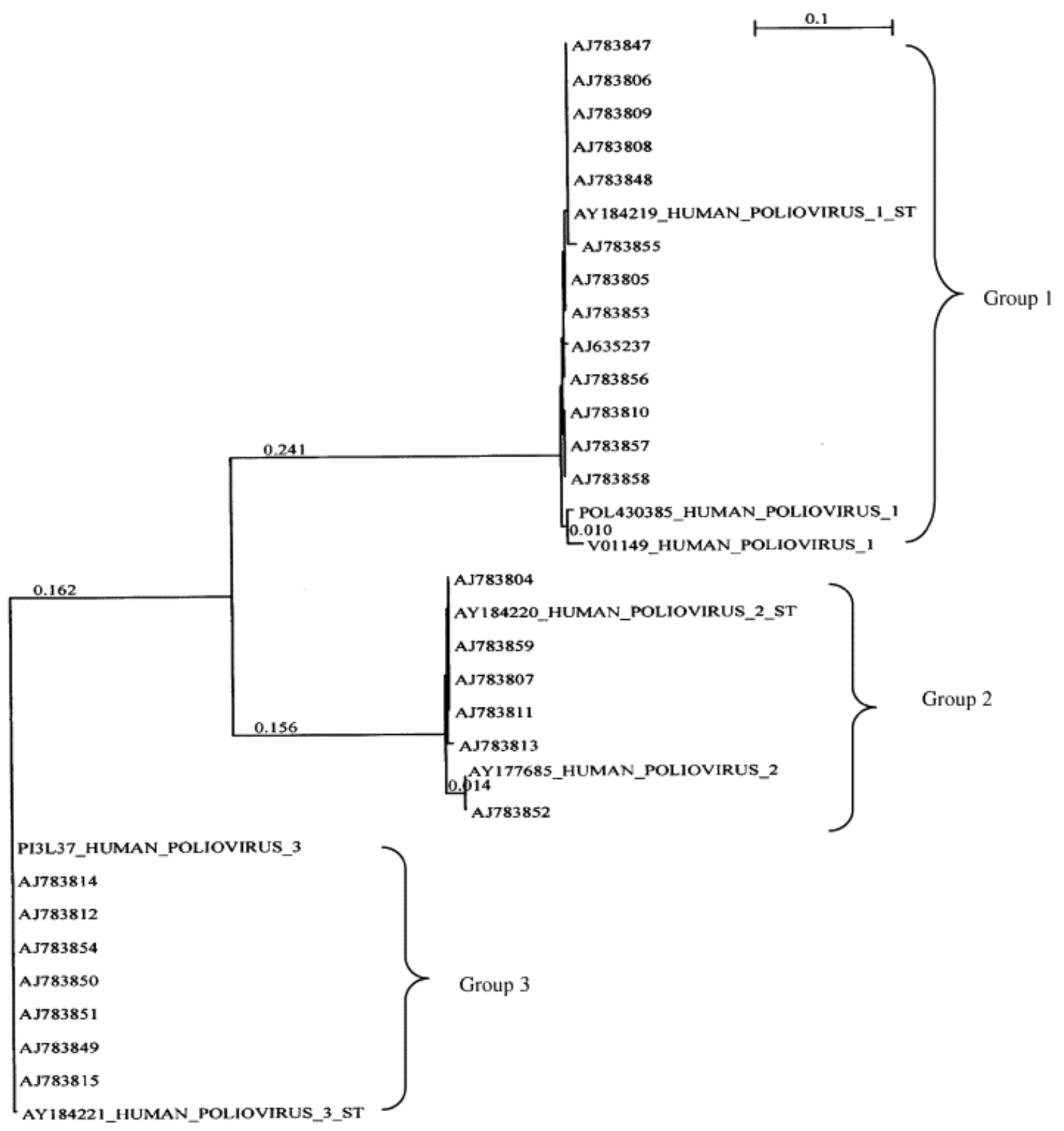

Fig. 2. Unrooted phylogenetic tree re-constructed with the neighbour-joining method from the comparative VP1 region sequence analysis of the sewage isolated oral poliovirus vaccine strains and the poliovirus reference strains. Branch lengths are 
proportional to the phylogenetic distances, while the vertical branches are noninformative. The scale bar shows $10 \%$ nucleotide sequence difference.

Group 2 consisted of PV type 2 isolates (Fig. 2). Isolate AJ783811AJ783811 showed $100 \%$ nucleotide sequence similarity to the attenuated Sabin PV type 2 (AY184220AY184220) reference strain (Table 5). Three PV type 2 isolates (AJ783804AJ783804, AJ783807AJ783807 and AJ783852AJ783852) differed at 0.2\% and isolate (AJ783813AJ783813) at $0.7 \%$ of VP1 sequences from the attenuated AY184220AY184220 strain. One of the isolates (AJ783852AJ783852) showed 100\% nucleotide sequence similarity to the AY177685AY177685 reference strain and had the highest divergence in VP1 sequences $(>1.4 \%)$ from the attenuated AY184220AY184220 reference strain.

Group 3 consisted of PV type 3 isolates (Fig. 2). All PV type 3 isolates (AJ783812AJ783812, AJ783814AJ783814, AJ783815AJ783815, AJ783849AJ783849, AJ783850AJ783850, AJ783851AJ783851, AJ783854AJ783854) showed 100\% nucleotide sequence identity with the neurovirulent PV reference strain P3/Leon/37 (PI3L37PI3L37) and diverged at $0.2 \%$ from the attenuated Sabin PV type 3 (AY184221AY184221) reference strain (Table 5). All isolates (AJ783812AJ783812, AJ783814AJ783814, AJ783815AJ783815, AJ783849AJ783849, AJ783850AJ783850, AJ783851AJ783851 and AJ783854AJ783854) had in their sequenced VP1 regions a mutation at position 2493 , which involved the reversion of a $C$ base (found in the attenuated vaccine strain) to a $\mathrm{T}$ base (found in the neurovirulent strain). This mutation involved the substitution of threonine (Thr) to isoleucine (Ile) at residue 6 of capsid protein VP1 (VP1-6). According to scientific reports, the presence of this mutation may be involved with reversion to increased neurovirulence of Sabin PV type 3 strains (Tatem et al., 1992; Macadam et al., 1993; Georgescu et al., 1997; Minor, 1999; Martin and Minor, 2002).

In this study, the majority of the OPV isolates (24 out of 26 PVs) displayed close sequence relationships ( $>99 \%$ VP1 sequence identity in the partially sequenced region) to the parental Sabin PV vaccine strains (Table 5). Based on a recent WHO Classification (2004), these isolates were classified as "OPV-like viruses". In addition, four Sabin-like type 1 PVs (Ts1, Sbnd2, Lv1 and Mb1) showed 100\% nucleotide sequence identity to the attenuated Sabin PV type 1 vaccine strain in both the partial VP1 region as well as the partial 5'UTR.

Seven Sabin-like type 1 PVs (D2, DP1 09/13, KspntDR, Mcc1, Mcc4, MF3 and Sbnd1) and one Sabin-like type 2 PV (OF2 05/21) showed approximately $0.5-0.8 \%$ divergence in the partially sequenced VP1 region from the attenuated Sabin PV vaccine strains. By assuming that the rate of VP1 evolution (approximately $1-2 \%$ change $\mathrm{yr}^{-1}$ ) was constant over the entire period of replication and similar to the rates observed for the other types of PVs, and without correcting for the small effects of multiple substitutions at site, it can 
be estimated that the total period of replication for these PV isolates was between 5 and 8 months.

Two isolates (D1 08/28 and OF1 05/21) were classified as "suspected" VDPVs, since these isolates showed $\leqslant 99 \%$ VP1 sequence identity in their partially sequenced region to the parental Sabin PV vaccine strains. Isolate OF2 05/21 (a "suspected" VDPV type 1) showed $>0.9 \%$ divergence in the partially sequenced VP1 region, whereas isolate D1 08/28 (a "suspected" VDPV type 2) showed the highest percentage divergence (at 1.4\%). As with most of the other OPV-like isolates, these "suspected" VDPVs carried mutations at specific positions in their partially sequenced regions (5'UTR and VP1), which have been associated with reversion of the attenuated Sabin PV vaccine strains to increased neurovirulence. The extent of sequence divergence of OF1 05/21 and D1 08/28 suggested that these "suspected" VDPVs had replicated in one or more people from 12 to 16 months since the administration of the initiating OPV dose. These results were in agreement with findings from other studies, in which VDPVs (with 1.4\% nucleotide divergence from the vaccine strain) were isolated from sewage and river waters within 3 months following OPV vaccination (Horie et al., 2002; Yoshida et al., 2002). Several of these reported VDPV type 1 and 3 isolates showed increased neurovirulence (Horie et al., 2002; Yoshida et al., 2002).

\section{Conclusions}

The risk of infection with VDPVs from river water can be considerably high, taking into account, that access to rural river water is easy for many individuals using this water for washing and drinking purposes. However, the risk of infection with VDPVs from sewage is very low, but not zero, since in some instances raw sewage is used for irrigation purposes and in this way individuals may be directly exposed to VDPVs present in the sewage (Yoshida et al., 2002). The survival in the environment of VDPVs excreted by humans is of concern, because these PVs might be transmitted and continue to circulate in a non-immune population after the cessation of polio vaccination (Friedrich, 2000; Buttinelli et al., 2003).

Two conclusions could be drawn from this study. Sequencing confirmed the typing results and more importantly, sequencing gave no indication of an intertypic recombination event between the 5'UTR and the VP1 part of the PV genome. Nonetheless, the identification of OPV-like viruses and "suspected" VDPVs in this study emphasised that there is a potential environmental risk of VAPP as long as the attenuated live OPV is not replaced by the inactivated poliovirus vaccine in the near future. 


\section{References}

Bellmunt et al., 1999 A. Bellmunt, G. May, R. Zell, P. Pring-Akerblom, W. Verhagen and A. Heim, Evolution of poliovirus type I during 5.5 years of prolonged enteral replication in an immunodeficient patient, Virology 265 (1999), pp. 178-184.

Blomqvist et al., 2004 S. Blomqvist, C. Savolainen, P. Laine, P. Hirttiö, E. Lamminsalo, E. Pentillä, S. Jöks, M. Roivainen and T. Hovi, Characterisation of a highly evolved vaccine-derived poliovirus type 3 isolated from sewage in Estonia, J. Virol. 78 (2004), pp. 4876-4883.

Buttinelli et al., 2003 G. Buttinelli, V. Donati, S. Fiore, J. Marturano, A. Plebani, P. Balestri, A. Soresina, R. Vivarelli, F. Delpeyroux, J. Martin and L. Fiore, Nucleotide variation in Sabin type 2 poliovirus from an immuno-deficient patient with poliomyelitis, J. Gen. Virol. 84 (2003), pp. 1215-1221.

Centers for Disease Control and Prevention, 2003 Centers for Disease Control and Prevention, Progress toward poliomyelitis eradication-Southern Africa, 2001-March 2003, Morbid. Mortal. Week. Rep. 52 (2003), pp. 521-524.

Chezzi, 1996 C. Chezzi, Rapid diagnosis of poliovirus infection by PCR amplification, J. Clin. Microbiol. 34 (1996), pp. 1722-1725.

Divizia et al., 1999 M. Divizia, L. Palombi, E. Buonomo, D. Donia, V. Ruscio, M. Equestre, L. Leno, A. Pana and A.M. Degener, Genomic characterisation of human and environmental polioviruses isolated in Albania, Appl. Environ. Microbiol. 65 (1999), pp. 3534-3539.

Egger et al., 1995 D. Egger, L. Pasamontes, M. Ostermayer and K. Bienz, Reverse transcription multiplex PCR for differentiation between polio- and enteroviruses from clinical and environmental samples, J. Clin. Microbiol. 33 (1995), pp. 1442-1447.

Equestre et al., 1991 M. Equestre, D. Genovese, F. Cavalieri, L. Fiore, R. Santoro and R.P. Bercoff, Identification of a consistent pattern of mutations in neurovirulent variants derived from the Sabin vaccine strain of poliovirus type 2, J. Virol. 65 (1991), pp. 27072710 .

Felsenstein, $1981 \mathrm{~J}$. Felsenstein, Evolution trees from DNA sequences: a maximum likelihood approach, J. Mol. Evol. 17 (1981), pp. 368-376.

Friedrich, 2000 F. Friedrich, Genomic modifications in oral poliovirus vaccine strains after multiplication in humans and implications for the eradication of poliovirus, Acta Virol. 44 (2000), pp. 109-117. 
Georgescu et al., 1997 M.M. Georgescu, J. Balanant, A. Macadam, D. Otelea, M. Combiescu, A.A. Combiescu, R. Crainic and F. Delpeyroux, Evolution of the Sabin type 1 poliovirus in humans: characterization of strains isolated from patients with vaccineassociated paralytic poliomyelitis, J. Virol. 71 (1997), pp. 7758-7768.

Guillot et al., 2000 S. Guillot, V. Caro, N. Cuervo, E. Korotkova, M. Combiescu, A. Persu, A. Aubert-Combiescu, F. Delpeyroux and R. Crainic, Natural genetic exchanges between vaccine and wild poliovirus strains in humans, J. Virol. 74 (2000), pp. 8434 8443.

Higgins and Sharp, 1988 D.G. Higgins and P.M. Sharp, Clustal: a package for performing multiple sequence alignment on a microcomputer, Gene 73 (1988), pp. $237-$ 244.

Horie et al., 2002 H. Horie, H. Yoshida, K. Matsuura, M. Miyazawa, K. Wakabayashi, A. Nomoto and S. Hashizume, Isolation of vaccine-derived type 1 polioviruses displaying similar properties to virulent wild strain Mahoney from sewage in Japan, J. Med. Virol. 68 (2002), pp. 445-451.

Hyypiä et al., 1989 T. Hyypiä, P. Auvinen and M. Maaronen, Polymerase chain reaction for human picornaviruses, J. Gen. Virol. 70 (1989), pp. 3261-3268.

Kew et al., 1998 O.M. Kew, R.W. Sutter, B.K. Nottay, M.J. MacDonough, D.R. Prevots, L. Quick and M.A. Pallansch, Prolonged replication of a type 1 vaccine-derived poliovirus in an immunodeficient patient, J. Clin. Microbiol. 36 (1998), pp. 2893-2899.

Kew et al., 2004 O.M. Kew, P.F. Wright, V.I. Agol, F. Delpeyroux, H. Shimizu, N. Nathanson and M.A. Pallansch, Circulating vaccine-derived polioviruses: current state of knowledge, Bull. WHO 82 (2004), pp. 16-23.

Li et al., 1996 J. Li, L.B. Zhang, T. Yoneyama, H. Yoshida, H. Shimizu, K. Yoshii, M. Hara, T. Nomura, H. Yoshikura, T. Miyamura and A. Hagiwara, Genetic basis of the neurovirulence of type 1 polioviruses isolated from vaccine-associated paralytic patients, Arch. Virol. 141 (1996), pp. 1047-1054.

Macadam et al., 1993 A.J. Macadam, S.R. Pollard, G. Ferguson, R. Skuce, D. Wood, J.W. Almond and P.D. Minor, Genetic basis of attenuation of the Sabin type 2 vaccine strain of poliovirus in primates, Virology 192 (1993), pp. 18-26.

Manor et al., 1999 Y. Manor, R. Handsher, T. Halmut, M. Neuman, B. Abramovitz, A. Mates and E. Mendelson, A double-selective tissue culture system for isolation of wildtype poliovirus from sewage applied in a long term environmental surveillance, Appl. Environ. Microbiol. 65 (1999), pp. 1794-1797.

Martin and Minor, 2002 J. Martin and P.D. Minor, Characterisation of CHAT and Cox type 1 live-attenuated poliovirus vaccine strains, J. Virol. 76 (2002), pp. 5339-5349. 
Martin et al., 2000 J. Martin, G. Dunn, R. Hull, V. Patel and P.D. Minor, Evolution of the Sabin strain of type 3 poliovirus in an immunodeficient patient during the entire 637-day period of virus excretion, J. Virol. 74 (2000), pp. 3001-3010.

Minor, 1985 P.D. Minor In: B.W.J. Mahy, Editor, Virology: A Practical Approach, IRL Press, Oxford, Washington, DC (1985).

Minor, 1992 P.D. Minor, The molecular biology of poliovaccines, J. Gen. Virol. 73 (1992), pp. 3065-3077.

Minor, 1999 P.D. Minor, Poliovirus vaccination: current understanding of poliovirus interactions in humans and implications for the eradication of poliomyelitis, Expert Rev. Mol. Med. (1999).

Minor and Dunn, 1988 P.D. Minor and G. Dunn, The effect of sequences in the 5'noncoding region on the replication of polioviruses in the human gut, J. Gen. Virol 69 (1988), pp. 1091-1096.

Shulman et al., 2000 L.M. Shulman, R. Handsher, C.F. Yang, S.J. Yang, J. Manor, A. Vonsover, Z. Grossman, M. Pallansch, E. Mendelson and O.M. Kew, Resolution of the pathways of poliovirus type 1 transmission during an outbreak, J. Clin. Microbiol. 38 (2000), pp. 945-952.

Tatem et al., 1992 J.M. Tatem, C. Weeks-Levy, A. Georgiu, S.J. DiMichele, E.J. Gorgacz, V.R. Racaniello, F.R. Cano and S.J. Mento, A mutation present in the amino terminus of Sabin 3 poliovirus VP1 protein is attenuating, J. Virol. 66 (1992), pp. 31943197.

Wood and Thorley, 2003 N. Wood and B. Thorley, Viewpoint towards global poliomyelitis eradication: the successes and challenges for a developed country, J. Paed. Child Health 39 (2003), pp. 647-650.

World Health Organization, 2002 World Health Organization, Expanding contributions of the global laboratory network for poliomyelitis eradication, Week. Epidemiol. Record 77 (2002), pp. 133-137.

World Health Organization, 2004 World Health Organization, 2004. Manual for the virological investigation of poliomyelitis. Geneva, Switzerland: World Health Organization (WHO/EPI/GEN/04).

Yang et al., 1991 C.-F. Yang, L. De, B.P. Holloway, M.A. Pallansch and O.M. Kew, Detection and identification of vaccine-related polioviruses by the polymerase chain reaction, Virus Res. 20 (1991), pp. 159-179.

Yang et al., 1992 C.F. Yang, L. De, S.J. Yang, J.R. Gòmez, J.R. Cruz, B.P. Holloway, M.A. Pallansch and O.M. Kew, Genotype-specific in vitro amplification of sequences of 
the wild type 3 polioviruses from Mexico and Guatemala, Virus Res. 24 (1992), pp. 277296.

Yoshida et al., 2002 H. Yoshida, H. Horie, K. Matsuura, T. Kitamura, S. Hashizume and T. Miyamura, Prevalence of vaccine-derived polioviruses in the environment, J. Gen. Virol. 83 (2002), pp. 1107-1111. 